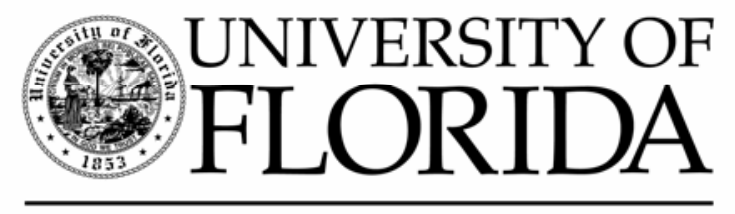

\title{
IFAS EXTENSION
}

\section{Planning, Conducting, and Evaluating the County Leadership Program $^{1}$}

\section{Elizabeth B. Bolton²}

\footnotetext{
${ }^{1}$ This document is FCS9204, one of a series of the Department of Family, Youth and Community Sciences, Florida Cooperative Extension Service, Institute of Food and Agricultural Sciences, University of Florida. Original publication date March 2005. Visit the EDIS Web Site at http://edis.ifas.ufl.edu.

2

Elizabeth B. Bolton, PhD, professor, Department of Family, Youth and Community Sciences, University of Florida, Gainesville, FL 32611.

The Institute of Food and Agricultural Sciences is an equal opportunity/affirmative action employer authorized to provide research, educational information and other services only to individuals and institutions that function without regard to race, color, sex, age, handicap, or national origin. For information on obtaining other extension publications, contact your county Cooperative Extension Service office. Florida Cooperative Extension Service / Institute of Food and Agricultural Sciences / University of Florida / Larry R. Arrington, Dean.
} 


\section{Contents}

Introduction...............................................................

Section 1 Program Development ................................................................ 6

Section 2 The Role of the County Faculty Member ............................... 7

Section 3 Planning Guide............................................................................. 8

Section 4 The Advisory Committee as Part of the ...................................

Community Leadership Program ......................................... 12

Letter 1, to Advisory Committee Members for First Meeting ............ 15

Identifying Existing and Potential County Leaders ............................. 16

Attachment 1, Advisory Committee Meeting Agenda ........................ 18

Attachment 2, Schedule of Meetings .................................................... 19

Letter 2, to Advisory Committee Members After Initial Meeting..... 20

Attachment 3, Participation Selection Checklist................................. 22

Section 5 Program Budget...............................................23

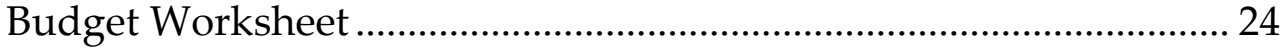

Section 6 Class Organization.......................................25

Four Methods of Identifying Community Leaders ............................... 28

Summary of Leader Identification Procedures ................................... 29

Letter 3, to Potential Participants .............................................................. 31

Letter $4 \mathrm{a}$, to Opening Ceremony Invitation, Participant .................... 32

Letter $4 \mathrm{~b}$, to Opening Ceremony Invitation, Participant .............33

Letter 5, to Opening Ceremony Speaker ................................................ 34

Letter 6, to Opening Ceremony Invitation to VIP Guests .................... 36

Letter 7, to Advisory Committee Members

Announcing Opening Ceremony ………………………....... 37

Attachment 4, Class Roster Information Sunshine County ................. 38

Letter 8, to Selected VIPs On Class Progress .......................................... 41

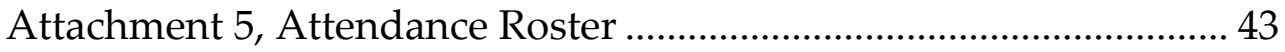

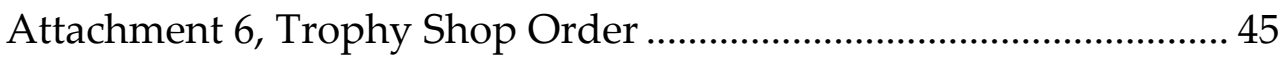

Letter 9, to Graduation Invitation to Class Participants ...................... 47

Letter 10, to Graduation Speaker .......................................................... 47

Letter 11a, to Graduation Invitation to VIPs who Attended

Opening Ceremony ……...................................................... 48 
Letter $11 \mathrm{~b}$, to Graduation Invitation to VIPs who did not Attend Opening Ceremonies .................................................. 50

Letter 12, to Graduation Invitation to Class Instructors ....................... 51

Letter 13, to Graduation Invitation Advisory Committee Members 52 Attachment 7, Program for Opening Ceremony …………………..... 53

Attachment 8, Program for Graduation ................................................. 54

Attachment 9, Physical Arrangement for Opening Ceremony and/or Graduation ............................................... 55

Section 7 Publicity and Media Package.................................................. 56

Section 8 Meeting Preparartion.........................................................58

Attachment 10, Classroom Arrangement .............................61

Section 9 Resource Directory ................................................................6 62

Section 10 Data Collection and Evaluation........................................64

Record of Local Contributions Sunshine County ……........................ 65

Attachment 11, Sunshine County Leadership

Development Program ................................................. 66

Section 11 Alumni Activities ..................................................................69 69

Participant Recommendations............................................................. 70

References .............................................................73 


\section{Introduction}

Citizen participation is vital to a democratic society in which people make decisions about issues affecting their lives and welfare. If these decisions are to reflect the general good of the community, people must participate as individuals or as members of organizations and institutions. County Leadership Programs strengthen communities and counties by developing the most available, yet under utilized, resource in the community - the human resources of all ages, socioeconomic classes, and ethnicities that make up the citizenry.

The objective of this workshop is to prepare Extension county faculty to develop a program that increases the number of local leaders who can:

a) identify and resolve issues of local and regional interest,

b) participate effectively in local organizations, and

c) be a spokesperson for the local Extension program.

This workshop is designed to assist county faculty in all aspects of the County Leadership Program. Twelve topical sections are covered which reflect the major steps of planning, conducting and evaluating the County Leadership Program. In each section, a series of work sheets is included so that a user can "walk through" each step of the process. A narrative of each step is not included because it is intended that the county faculty will tailor the specifics to fit his/her own county situation. Further, each step should be modified with new materials and information relevant to the county, program or situation. The following are the topical sections covered:

1. Program Development

2. Role of Extension County Faculty

3. Planning Guide

4. Advisory Committee

5. Program Budget

6. Class Organization

7. Publicity and Media Package

8. Meeting Preparation

9. Resource Directory

10. Data Collection and Evaluation

11. Alumni Activities

12. Miscellaneous 
It is important to keep in mind that the County Leadership Program follows many of the basic steps in program development generic to all Extension programs. With this approach in mind, the task becomes one of using a familiar model-program development-on a new program, with a new target group, and a new set of outcomes and accomplishments that will permeate all other Extension programs in which the leadership class members participate. Major differences between the leadership model and traditional program development are: (a) the inclusion of an opening ceremony and a graduation ceremony, and (b) the emphasis on an alumni group of program graduates. Like other Extension programs, the County Leadership Program focuses on applying increased personal skills and knowledge gain to benefit the community in a variety of ways.

Note:

The leadership curriculum for the class sessions is not included in this set of materials. these are available from members of the FL 513 design team. As county faculty teach the leadership classes, it is appropriate to develop a set of local materials. Local speakers may also prefer to have their own materials for class presentations.

With the continuing interest in program outcomes and accountability, it is essential to plan an evaluation component. A form that is used consistently with FL 513 county programs is included in Section 10, Evaluation. County faculty are encouraged to use this form to report on an annual basis. In this way, the leadership work that takes place throughout the year can accrue to the program and involved faculty.

Bolton, E.B. (1994 rev.). FL513 program accomplishments and impacts: Leadership programs and utilization of volunteers. Gainesville, FL: Cooperative Extension Service: University of Florida. 


\section{Section 1}

\section{Program Development}

A. Assess the status of the current leadership base. Have there been any other leadership programs in the county in the past few years?
a. Who was involved?
b. What were the outcomes?
c. What were the costs?

B. What clubs, organizations, associations, and groups are there in the county? List these. By each one indicate significant projects these groups or organizations have contributed to the community.

C. Is there a feeling of community in your county? Why do you think your answer is true? Are people generally willing to get involved? What is the usual kind of involvement?

D. Who makes decisions for the community? Are they well informed? Who influences them? How have you determined this?

E. Realize that other people in your county may not have given much thought to the need for a leadership program

F. Resist making all the decisions by yourself.

G. List the benefits a leadership program has for your county?

H. What are the programming implications for Extension?

I. What are the implications for your county? 


\section{Section 2}

\section{The Role of the County Faculty Member}

What is your role in the community? How are you viewed as a community leader?

The Community Leadership Program is important to you for the following reasons.

- It involves components of, or has important implications for ALL Extension program areas.

- It proves an excellent opportunity to work with a diverse mix of countywide clientele.

- It increases your knowledge of available and potential local resources and volunteers.

- It significantly and positively expands the participant's view of the diverseness of Extension.

- It broadens the local, and consequently the state, base of support that is essential for Cooperative Extension programs to be successful.

The Role Of The County Faculty Member:

- Educator

- Local change agent

- Planner/organizer

- Fund-raiser

- Group facilitator

- Media/publicity coordinator 


\section{Section 3}

\section{Planning Guide}

\begin{tabular}{|l|l|l|}
\hline \multicolumn{1}{|c|}{ Activity } & $\begin{array}{c}\text { Tentative } \\
\text { Dates } \\
\text { Completed }\end{array}$ & $\begin{array}{c}\text { Date } \\
\text { Comp secure }\end{array}$ \\
\hline $\begin{array}{l}\text { 1. Decide on cosponsors for the program and } \\
\text { commitment }\end{array}$ & \\
\hline 2. Develop a program budget (See Section 5) & \\
\hline $\begin{array}{l}\text { 3. Organize the Advisory Committee and hold a } \\
\text { planning meeting (See Section 4) }\end{array}$ & \\
\hline $\begin{array}{l}\text { 4. Send a letter of invitation for the first meeting to } \\
\text { Advisory Committee members (attach list to identify } \\
\text { existing and potential community leaders) (See } \\
\text { Section 4, Letter 1) }\end{array}$ & & \\
\hline $\begin{array}{l}\text { 5. Complete Advisory Committee meeting agenda (See } \\
\text { Section 4, Attachment 1) }\end{array}$ & & \\
\hline $\begin{array}{l}\text { (See Section 4, Attachment 2) } \\
\text { for opening ceremony and graduation }\end{array}$ & & \\
\hline
\end{tabular}




\begin{tabular}{|c|c|c|}
\hline Activity & $\begin{array}{l}\text { Tentative } \\
\text { Dates }\end{array}$ & $\begin{array}{c}\text { Date } \\
\text { Completed }\end{array}$ \\
\hline $\begin{array}{l}\text { 8. Send letter to Advisory Committee Members after } \\
\text { initial meeting (See Section 4, Letter 2) }\end{array}$ & & \\
\hline $\begin{array}{l}\text { 9. Contact potential class participants (See Section 6, } \\
\text { Letter 3) }\end{array}$ & & \\
\hline $\begin{array}{l}\text { 10. Complete opening ceremony programs for printing } \\
\text { (See Section 6, Attachment 7) }\end{array}$ & & \\
\hline $\begin{array}{l}\text { 11. Complete participant roster form, (See section 6, } \\
\text { Attachment 5) }\end{array}$ & & \\
\hline $\begin{array}{l}\text { 12. Complete participant selection checklist (See Section } \\
\text { 4, Attachment 3) }\end{array}$ & & \\
\hline $\begin{array}{l}\text { 13. Invite local VIP guests to opening Ceremony (See } \\
\text { Section 6, Letter 6) }\end{array}$ & & \\
\hline $\begin{array}{l}\text { 14. Invite Advisory Committee Members who are not in } \\
\text { class to Opening Ceremony (See Section 6, Letter 7) }\end{array}$ & & \\
\hline $\begin{array}{l}\text { 15. Prepare for Opening Ceremony (See Section 6, } \\
\text { Attachment 9) }\end{array}$ & & \\
\hline $\begin{array}{l}\text { 16. Prepare schedule of meetings form for distribution at } \\
\text { opening ceremony (See Section } 4 \text {, Attachment 2). }\end{array}$ & & \\
\hline
\end{tabular}




\begin{tabular}{|l|l|l|}
\hline Activity & $\begin{array}{c}\text { Tentative } \\
\text { Dates }\end{array}$ & $\begin{array}{c}\text { Date } \\
\text { Completed }\end{array}$ \\
\hline 17. Plan publicity and media coverage (See Section 7) & & \\
\hline 18. Prepare for first and subsequent classes & & \\
\hline $\begin{array}{l}\text { 19. Mail payment for notebooks } \\
\text { 20. Invite selected VIP's to join class at their convenience; } \\
\text { send schedule of meetings form and letter (See Section } \\
\text { 6, Letter 8) }\end{array}$ & & \\
\hline $\begin{array}{l}\text { 21. Meet with state specialist and district director to } \\
\text { discuss alumni plans (See Section 11) }\end{array}$ & & \\
\hline $\begin{array}{l}\text { 22. Make decisions on classes 11 and 12 } \\
\text { 24. Order plaques (See Section 6, Attachment 6) }\end{array}$ & & \\
\hline $\begin{array}{l}\text { Attachment 9) } \\
\text { printing (See Section 6, Attachment 8) }\end{array}$ & & \\
\hline 23. Prepare for Graduation Ceremony (See Section 6, Letter 9) & & \\
\hline
\end{tabular}




\begin{tabular}{|l|l|l|}
\hline Activity & $\begin{array}{c}\text { Tentative } \\
\text { Dates }\end{array}$ & $\begin{array}{c}\text { Date } \\
\text { Completed }\end{array}$ \\
\hline $\begin{array}{l}\text { 27. Confirm arrangements with graduation Speaker (See } \\
\text { Section 6, Letter 10) }\end{array}$ & \\
\hline $\begin{array}{l}\text { 28. Invite VIPs who attended Opening Ceremony to } \\
\text { graduation. Also invite VIPs who were unable to } \\
\text { attend Opening Ceremony (See Section 6, Letters 11a } \\
\text { and 11b) }\end{array}$ & \\
\hline $\begin{array}{l}\text { 29. Invite Class instructors to Graduation Ceremony (See } \\
\text { Section 6, Letter 12) }\end{array}$ & & \\
\hline $\begin{array}{l}\text { 30. Invite members of the Advisory Committee who were } \\
\text { not class participants (See Section 6, Letter 13) }\end{array}$ & & \\
\hline 31. Prepare for final evaluation (See Section 10, \\
Attachment 10). & & \\
\hline
\end{tabular}




\section{Section 4}

\section{The Advisory Committee as Part of the Community Leadership Program}

Answer the following questions to decide whether or not to use a committee when planning the community leadership program.

A. Why Use an Advisory Committee?

1. Can the ideas and advice of an advisory committee help me plan a better program?

2. Am I willing to take the necessary time to interact with committee members to do whatever possible to insure effective decision-making?

3. Will the advisory committee assist with promoting the program?

4. Will the advisory committee's commitment assure a quality program?

B. What are the advantages of using an Advisory Committee?

1. Locally legitimize Extension's programming efforts in community leadership.

2. Discourage others from singling out Extension as being solely responsible for participant selection.

3. Save time, effort, and energy by not having to personally contact every potential participant.

4. Provide a broadened base of local resources and contacts.

5. Allow an opportunity to involve non-traditional leaders in learning firsthand about Extension and its diverseness.

C. Who should be included? Go for influential and effective community members.

D. What Happens Next?

(Anticipate having to answer these questions when you are recruiting advisory committee members.)

1. What is the community leadership program?

2. Who are the sponsors?

3. Who are the cosponsors? 
4. What will I be asked to do?

5. How much of a time investment will it require?

6. Why am I being asked to serve on this Advisory Committee?

7. What is the overall job of the Advisory Committee?

8. How does this program fit with other leadership programs?

E. Send a follow-up letter after a personal or phone contact (See Letter 1)

F. Organizing Your Committee Meeting

1. Reserve an impressive meeting facility.

2. Have a meeting agenda (See Attachment 1).

3. Do your homework.

4. Create a schedule of program dates (See Attachment 2)

5. Determine a suggested registration fee.

6. Create a list of suggested program participants. 


\section{Holding an Advisory Committee Meeting}

- Provide light refreshments

- Display the program materials

- Circulate the agenda and the list of members

- Welcome and introduce everyone

- Explain Extension's interest in and support of the community leadership program

- Answer questions and further explain how the program will fit the county's needs (Attachment 1)

- Develop a list of potential participants (Attachment 3)

- Divide the final list of potential participants

- Let advisory committee members help make contacts

- Develop a list of VIP's to be invited to the opening ceremony and graduation

- Decide on the top speakers for the opening ceremony and graduation

- Review the list of meeting sites for each session

- Develop a list of potential donors and contributors

- Summarize the decisions and assignments

- Express thanks to committee and adjourn

- Send a letter to advisory committee members with attachment (Letter 2) 


\section{Letter to Advisory Committee Members for the First Meeting}

(DATE)

(INSIDE ADDRESS OF MEMBER)

Dear

Thank you for agreeing to meet and discuss an exciting new program, "Community Leadership for Sunshine County." As one of Sunshine County's key leaders, your support and interest are vital to the overall success of the program.

I look forward to sharing more information about the program with you at our meeting on (date, time, and location). Would you please complete the attached form and bring it to our meeting. This information will save time and it will be useful to our planning procedure.

Very truly yours,

County Extension Faculty Name Title 


\section{Identifying Existing and Potential County Leaders}

You are one of our county leaders and a good source of information about all aspects of the county. In your opinion, who are our influential county leaders in the following categories? This information will assist us as we plan a community leadership program for Sunshine County. The information you share on this form will be used for internal planning purposes only; it will not be seen by anyone else. Thank you for your help.

A person's name may appear in more than one area of expertise; list as many different names as possible, including locally recognized influential minority leaders.

\begin{tabular}{|c|c|}
\hline BUSINESS \& INDUSTRY & EDUCATION \\
\hline & \\
\hline & MEDICAL/HEALTH \\
\hline POLITICS & \\
\hline & NEWS/MEDIA \\
\hline RELIGION & \\
\hline & \\
\hline & CIVIC AFFAIRS \\
\hline & \\
\hline SOCIAL SERVICES & \\
\hline & \\
\hline
\end{tabular}




\begin{tabular}{|l|l|}
\hline \multicolumn{1}{|c|}{ CITY } & \multicolumn{1}{|c|}{ COUNTY } \\
\hline & \\
\hline & \\
\hline $\begin{array}{l}\text { List in the order of general community influences five or six of the most influential } \\
\text { organizations or groups in your county. }\end{array}$ \\
\hline 1. & 2. \\
\hline 3. & 4. \\
\hline 5. & 6. \\
\hline $\begin{array}{l}\text { So that we will have all communities represented within the county, please list leaders } \\
\text { from geographic areas. Some of the names for this section may have already been listed } \\
\text { above. }\end{array}$ & Community/town: \\
\hline Community/town: & \\
\hline Community/town: & Community/town: \\
\hline Community/town: & Community/town: \\
\hline & \\
\hline
\end{tabular}


Attachment 1

\section{Community Leadership Program Advisory Committee Meeting}

(Location)

(Date)

(Time)

\section{AGENDA}

Welcome

(County Faculty Name)

Introductions

Display of Program Materials

Questions and Answers

Plan for Sunshine County Leadership Program

Adjourn

(Prepare for distribution at this meeting a list of everyone who is on the committee include title, address, and telephone number.) 


\section{Schedule of Meetings}

County:

Program Coordinator:

Time:

\begin{tabular}{|c|c|c|c|}
\hline DATE & LOCATION & CONTENT/ACTIVITY & STAFF \\
\hline & & Opening Ceremony & \\
\hline & & $\begin{array}{l}\text { Basic Leadership: An Individual Perspective } \\
\text { Class 1: An Overview of Leadership }\end{array}$ & \\
\hline & & Class 2: A Focus on Individual Values & \\
\hline & & $\begin{array}{l}\text { Class 3: A Focus on Individual Leadership } \\
\text { Style }\end{array}$ & \\
\hline & & Class 4: Group Formation and Motivation & \\
\hline & & Class 5: Group Maintenance & \\
\hline & & Class 6: Group Process Skills & \\
\hline & & Class 7: Group Management & \\
\hline & & $\begin{array}{l}\text { Applied Leadership: A Community } \\
\text { Perspective } \\
\text { Class 8: Coalition Building }\end{array}$ & \\
\hline & & Class 9: Community Development & \\
\hline & & Class 10: Local Government & \\
\hline & & Class 11: County Perspective & \\
\hline & & $\begin{array}{l}\text { Class 12: Issue Identification and Planning for } \\
\text { the Future }\end{array}$ & \\
\hline & & Graduation Dinner & \\
\hline
\end{tabular}




\section{Letter to Advisory Committee Members After Initial Meeting}

(Date)

(Inside address)

Dear

Thank you for your interest in the Sunshine County Leadership Program. Your support at (date) meeting is appreciated. This program will be successful because of support from advisory committee members.

According to our discussion, you will be responsible for contacting (names of potential participants) by (deadline date).

To assist you in explaining the program and answering their questions, I have enclosed a schedule of meetings, participant commitment form, and a sample of the letter sent to potential participants.

We invite you to also join the charter class of SUNSHINE COUNTY COMMUNITY LEADERSHIP. Receiving your participant commitment form and \$_ registration fee would enroll you in the class. An additional form is enclosed for this purpose.

I will be in contact with you after (deadline date). Thanks again for your commitment to this program.

Very truly yours,

County Faculty Name

Title

Enclosures 


\section{Comments}

\section{Sunshine County Community Leadership}

Comments you might consider making to potential participants in addition to brochure information.

Why become involved?

a. For communities to grow and prosper, they require involvement from leaders like you.

b. You have an obligation to your community to make it the very best place in which to live.

c. In order for Sunshine County to grow and prosper along with neighboring counties, we must take steps now to insure its future growth and development by building a solid community leadership base.

d. You can make a contribution to your county even though you may not think of yourself as a leader. Other community members regard you as a leader.

e. Opportunities exist for alumni of this grassroots program to organize into a more formalized group in our county. 


\section{Participation Selection Checklist}

Note: Occupation/Profession: Check all that apply, but circle the check mark that represents the primary occupation/profession.

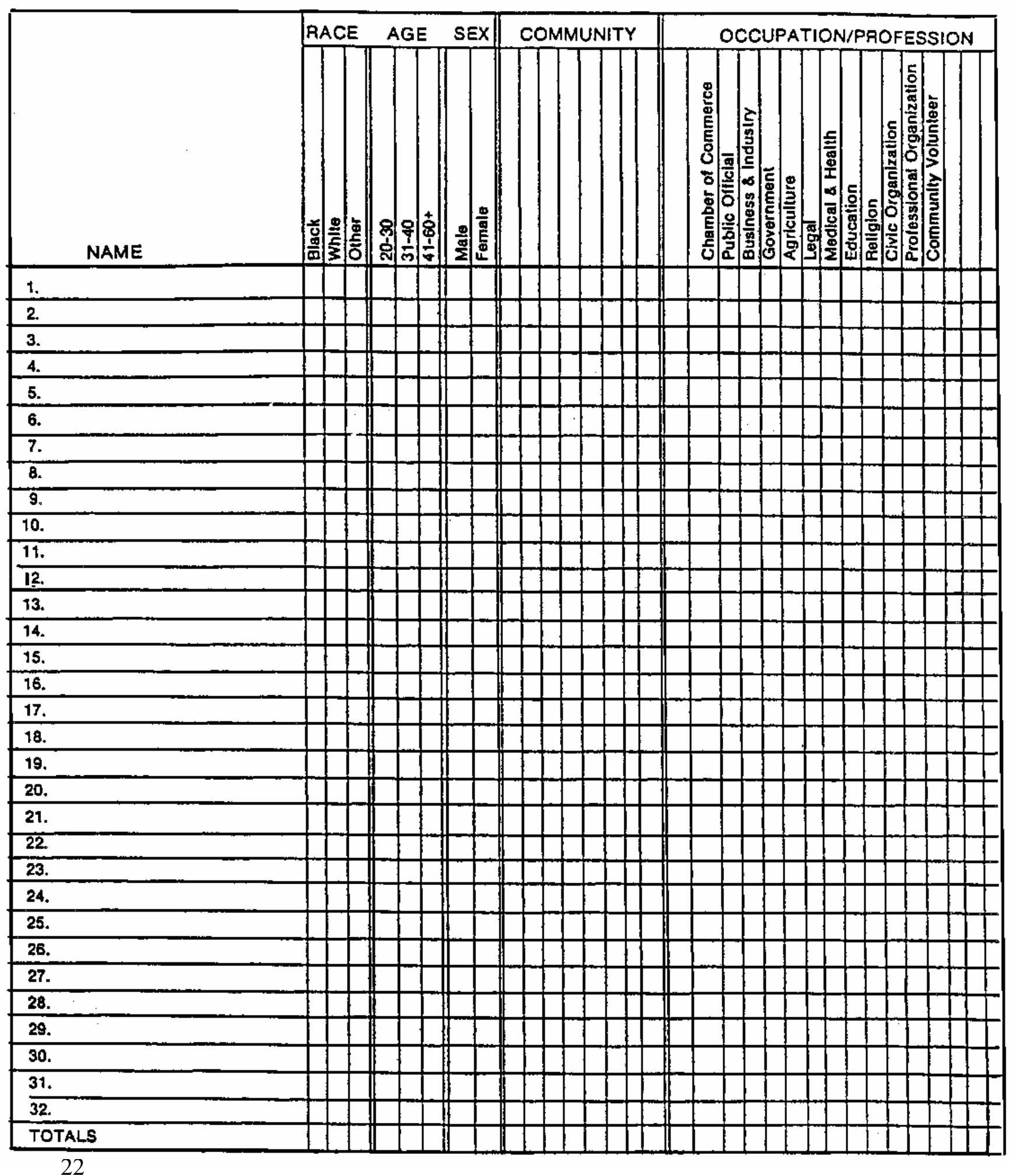




\section{Section 5}

\section{Program Budget}

Consider:

a. Local and state policies and procedures for securing financial support for a program

b. Getting financial help from cosponsors

c. How frugal or how elaborate the opening ceremony and graduation dinner will be

d. The clientele you are serving and the impression you make with you program

e. Fixed costs-materials, printing, notebooks, plaques

f. Variable costs - reception at opening ceremony, refreshments and paper good for classes, graduation dinner, postage on mailings, etc.

g. Optional costs - one day retreat, travel expense for tour or field trip

h. Letting each participant make a personal commitment to support his/her registration fee

i. Involve advisory committee in making recommendations on the level of expenditures 


\section{Budget Worksheet}

\section{Subtotal Total}

Participant Registration

$\underline{\text { Fees }}$

$$
\text { _ people @ \$ _ per person }
$$

$\$$

\section{Fixed costs}

Other

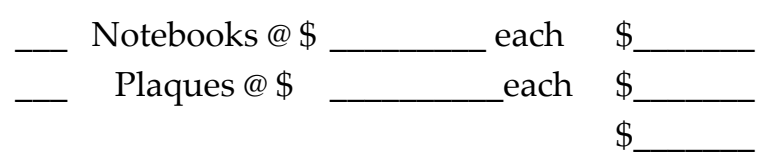

\section{Total Fixed Costs}

$\$$

\begin{tabular}{llll}
\hline Variable Costs & & \\
\hline Reception & people $@ \$$ & per person & $\$$ \\
Class Refreshments & people $@ \$$ & per person & $\$$ \\
Graduation Dinner & people $@ \$$ & per person & $\$$ \\
Postage (estimate) & &
\end{tabular}

Total Variable Costs

$\$$

\section{Optional Costs}

Localized Stationery/Envelopes

\section{$\underline{\text { Retreat }}$}

Facility Use Fee

Food/Refreshments

Other

Field Trip

Transportation

Food

Other

Gift, Fee, Travel Expense for Speakers
$\$$

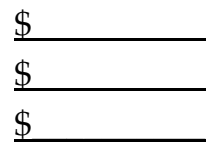

$\$$

$\$$
$\$$

$\$$

$\$$

\section{Contributions}

Cosponsor

Contributors

Other

$\$$

$\$$

$\$$

Total Contributions

$\$$

Balance

$\$$ 


\section{Section 6}

\section{Class Organization}

A. Participant Selection

1. Broad-based cross-section of participants (Use checklist, Section 4, Attachment 3)

2. Commitment

3. Potential

4. Look at four methods for selecting leaders

B. Participant Follow-up

1. With advisory committee compile a list of 45 to 50 names

2. Mail Letter 3 to each potential participant

3. Notify confirmed class participants of the Opening Ceremony with Letter 4a or $4 \mathrm{~b}$

4. Collect all participant commitment forms and registration fees by the deadline date prior to opening ceremony

5. Avoid adding last minute participants

C. Opening Ceremony

1. Special Invitations

- Confirm guest speakers (Letter 5)

a VIP Guests (Letter 6)

口 Advisory Committee (Letter 7)

2. Address List

- Develop master list

口 Remember franking rules

3. Printing of Opening Ceremony Program, include the following (See Attachment 7)

- County name

- Location of Opening Ceremony

- List of class participants in alphabetical order

- Name and title of person responsible for welcome

- Name and title of person responsible for introduction of class participants

- Name and title of keynote speaker

- Name and titles of Advisory Committee member

- Name of sponsors 
a Names of contributors

4. Participant Roster (See Attachment 4)

a Circulate to class members

5. Publicity (See Section 7)

- Use the media for publicity

6. Physical Arrangements (See Attachment 9)

D. Miscellaneous Considerations

口 Write letters of thanks after opening ceremony

- Keep in touch with selected VIP's as to class progress (See Letter 8)

- Collect all newspaper clippings

- Optional - take pictures of class in different settings

口 Check attendance at every session (See Attachment 5)

- Start planning graduation ceremony

E. Graduation Ceremony

1. Graduation Plaques (See Attachment 6)

2. Ceremony Invitations

- Class participants (See Letter 9)

- Graduation speakers (make appropriate changes for type of address, e.g. invocation, welcome, keynote, See Letter 10)

- VIP guests (See Letters 11a and 11b)

a Class instructors (See Letter 12)

- Advisory Committee members (See Letter 13)

3. Printing Graduation Program (See Attachment 8)

- County name

- Location of Graduation Ceremony

- Date and time

- List of graduation participants in alphabetical order who qualify for graduation

- Name and title of person responsible for Invocation if dinner is served

- Name and title of person responsible for Welcome and Opening Remarks

- Name and title of person responsible for Recognition of Sponsors and Contributors

- Name of two or three class members who will share with the audience 
two or three different perspectives of what the program has meant to them

- Name and title of keynote speaker

- Name and title of two responsible for awarding the plaques (One of these should be you, the county extension faculty member)

- Your name will be listed under Closing Comments

- Name and titles of Advisory Committee Members

- Names of sponsors

a Names of contributors

4. Publicity

See Section 7

5. Physical Arrangements (See Attachment 9)

F. Miscellaneous Considerations

- Letters of thanks to Advisory Committee members, cosponsors, contributors and media.

- Do something special for Extension Office support staff

- Meet with District Director and Extension Design Team to discuss:

- Recommendations for improving overall program

- Future plans

口 Potential outcomes 


\section{Four Methods for Identifying Community Leaders}

METHOD

1.

POSITIONAL positions of formal

organizations. Position

holders make decisions and

control resources.

2. Power is reflected in

REPUTATIONAL reputation. Knowledgeable members know power actors by reputation. Some power actors are concealed.

3.

DECISIONMAKING

4. SOCIAL
Power is acquired through participation in decisionmaking.

\section{Power acquired through} participation in and offices held in voluntary associations.

\section{LEADER IDENTIFIED}

Higher civil servants, corporation executives, elected and appointed formal office holders, voluntary association officers.

General leaders who are concealed as well as those visible to the public.

Instrumental leaders in the resolution of community issues.

Visible participants in activities of voluntary associations.

\section{ADVANTAGES}

Leaders are visible, thus easily identified and less costly. Insight into potential role. Good cross-section of leaders.

Identifies visible and concealed leaders. Determines leaders in several issue areas. Relative ease in carrying out technique

Instrumental leaders in the resolution of community issues.

Identifies active community leaders and those likely to be active in action programs.

\section{LIMITATIONS}

Positional leaders may not exercise their potential. Fails to identify informal leaders. Difficult to determine which positions do or do not have power.

Determining who is or is not knowledgeable. Reputed power may not be exercised power. Fails to identify specialized power holders.

Time consuming and costly. Fails to identify leaders who are "behind the scenes or in non-decisions."

Time consuming and costly. Fails to identify concealed leaders or specific area of participation. 


\section{Summary of Leader Identification Procedures}

1. Positional Method

Determine positions relevant to your community effort.

Collect names, addresses, and telephone numbers for the incumbents of these positions.

Maintain and update yearly lists of these position holders.

As new relevant positions are created, add them to the list.

2. Reputation Method

Select relevant issues areas.

Select an appropriate number of knowledgeable members.

Select appropriate kinds of knowledgeable members.

Develop an approach to use with knowledgeable members

Develop interview questions and questionnaire.

Write down your own perception of who has power.

Interview each knowledgeable member.

Decide criteria to be in power actor pool.

Check reliability.

Make adjustments based on reliability check.

Repeat the process every two or three years.

3. Decision-Making Method

Select a number of decisions representative of the selected issue area.

Include decisions that are highly relevant for your programs.

Trace the decision-making process in each decision from its initiation to completion by interviews, documents, newspapers, attending meetings, and personal contacts.

Determine who the leaders are for each decision and issue area.

Review new decisions of interest, determining whom the power actors are.

4. Social Participation Method

Select a number of key community voluntary associations.

Obtain lists of members, officers, directors, and committees for each selected voluntary association.

Compare and determine overlaps in membership, officers, board of directors, and committees.

Define those that have the greatest participation as a pool of community leaders. Update on a regular basis. 


\section{Conclusion}

These four methods have some tendency to identify different power actor people pools and different types of leaders. Overlap between the four methods identifying the same persons in the top leadership category is usually low (20-40\%), except between the positional and reputation methods $(74 \%)$. Therefore, to get the most comprehensive analysis, several methods should be considered.

Source: Tait, John L., Janet Bokemeier and Joe M. Bohlen. "Identifying the Community Power Actors: A Guide for Change Agents," North Central Regional Extension Publication 59. 


\section{Letter to Potential Participants}

(Date)

(Inside Address)

Dear :

This is your invitation to become actively involved in the exciting future of Sunshine County by participating in our Community Leadership program. Your name was submitted as a potential participant in this new leadership development program sponsored by (List sponsors).

The program includes an opening ceremony, twelve (12) class sessions, and a graduation ceremony. Classes will be held each (day) evening from (time) to (time). The program officially begins on (date) and ends on (date).

A brochure outline, the program and its benefits to both you and to Sunshine County are enclosed. Also enclosed is a form for registering for the program and the associated cost of $\$$. Please note that local donors and cosponsors underwrite other program costs.

You will be contacted by a member of the Leadership Advisory Committee within the next ___ days to any questions you may have about the program. In the meantime, should you need additional information, please feel free to call (agent's name and number).

We look forward to welcoming you as a member of the Charter Class of Sunshine County Community Leadership.

Very truly yours, (Singled by appropriate cosponsor representative)

Enclosures 


\section{Opening Ceremony Invitation to Participants with Spouses}

(Date)

(Name \& Address of Participant)

Dear :

Congratulations on being a member of the Charter Class of Sunshine County Community Leadership. Thanks in advance for returning your participant commitment form and registration fee if you have not already done so.

You will be honored at a reception on (date, location, time). (Name of spouse) is invited to attend. Please call (phone \#) by (deadline date) to confirm (his/her) attendance.

Again, (participant's name) you are to be commended for your interest and support in helping build and maintain a strong leadership base for Sunshine County. Seeing you on (date) will be a real pleasure.

Sincerely,

(Signed by appropriate cosponsor representatives) 


\section{Letter $4 \mathrm{~b}$}

\section{Opening Ceremony Invitation to Participant without a Spouse}

(Date)

(Name \& Address of Participant)

Dear :

Congratulations on being a member of the Charter Class of Sunshine County Community Leadership. Thanks in advance for returning your participant commitment form and registration fee if you have not already done so.

You will be honored at a reception on (date, location, time). You may invite a guest to join you for the reception. Please call (phone \#) by (deadline date) to confirm (his/her) attendance.

Again, (participant's name) you are to be commended for your interest and support in helping build and maintain a strong leadership base for Sunshine County. Seeing you on (date) will be a real pleasure.

Sincerely,

(Signed by appropriate cosponsor representatives) 
Letter 5

\section{Letter to Opening Ceremony Speaker}

(Date)

(Inside address)

Dear :

Thanks for agreeing to be on the program at the opening ceremony of Sunshine Community Leadership. You have the key role of bringing the official leadership charge to the class participants. Ceremony details are as follows:

WHAT: A reception and program honoring those who will be participating in 12 sessions of intensive leadership training. Dignitaries and their spouses or guests will be in attendance. We are expecting approximately people.

WHO: The class participants include key individuals from Sunshine County who represent diverse backgrounds and interests.

WHEN: (Date and time)

WHERE: (Location with directions if necessary)

YOUR ASSIGNMENT: To deliver a 20 minute charge to class participants about the importance and necessity of building local community leadership. Share with them what is possible when a community has a solid leadership base in place. Any way you can localize our state perspective to Sunshine County would certainly be appropriate. A brochure on this program is attached for your information.

PROGRAM FORMAT: The reception will be held first (approximately 45 minutes). The program will follow (approximately 1 hour). Others on the program include: (Give names and titles.) (Name) will introduce you.

Thanks for sending me the biographical sketch in advance. Again, (name), we appreciate your interest and support in helping get our Charter Community Leadership Class off to a successful start. If you need additional information, please give me a call at (Office 
number). We look forward to seeing you on (Date)

Very truly yours,

County faculty member Title

Enclosure 


\section{Opening Ceremony Invitation to VIP Guests}

(Date)

(Name and Address of VIP)

Dear :

You are invited as our special guest to honor those who will be participating in the Charter Class of Sunshine County Community Leadership program.

As a community leader, you recognize the need for and value of having a strong leadership base in our county. This program, which is sponsored by (list sponsors), is designed to further train and develop leaders and potential leaders in (Name) County.

The attached brochure gives an overview of the program.

Please come join us on (date) for a reception at (time) at (location). Thanks for calling (County faculty's phone number) by (deadline date), if you and (spouse by name/guest) will attend.

Sincerely,

(Signed by appropriate cosponsor representatives)

Enclosure 


\section{Letter to Advisory Committee Members Announcing Opening Ceremony}

(Date)

(Inside Address)

Dear :

You and your spouse (special guest) are invited to participate in a reception honoring those whom you nominated for Sunshine County Community Leadership. The reception is on (date, time, location). Please call (County faculty's office number) by (deadline date) if you and spouse (guest) can be with us.

As a member of the Advisory Committee, your continued interest and support are appreciated. Seeing you on the (date) will be a pleasure, (name).

Very truly yours,

(Signature of County faculty) 
Attachment 4

\section{Class Roster Information}

Sunshine County

\begin{tabular}{|c|c|c|}
\hline NAME & JOB TITLE & COMMUNITY TITLE (S) \\
\hline Example: John Doe & Good Body Cars & $\begin{array}{l}\text { City Council and } \\
\text { Chamber of Commerce }\end{array}$ \\
\hline \multicolumn{3}{|l|}{1.} \\
\hline \multicolumn{3}{|l|}{2.} \\
\hline \multicolumn{3}{|l|}{3.} \\
\hline \multicolumn{3}{|l|}{4.} \\
\hline \multicolumn{3}{|l|}{5.} \\
\hline \multicolumn{3}{|l|}{6.} \\
\hline \multicolumn{3}{|l|}{7.} \\
\hline \multicolumn{3}{|l|}{8.} \\
\hline \multicolumn{3}{|l|}{9.} \\
\hline \multicolumn{3}{|l|}{10.} \\
\hline \multicolumn{3}{|l|}{11.} \\
\hline \multicolumn{3}{|l|}{12.} \\
\hline \multicolumn{3}{|l|}{13.} \\
\hline \multicolumn{3}{|l|}{14.} \\
\hline \multicolumn{3}{|l|}{15.} \\
\hline \multicolumn{3}{|l|}{16.} \\
\hline \multicolumn{3}{|l|}{17.} \\
\hline \multicolumn{3}{|l|}{18.} \\
\hline \multicolumn{3}{|l|}{19.} \\
\hline \multicolumn{3}{|l|}{20.} \\
\hline 21. & & \\
\hline
\end{tabular}




\begin{tabular}{||l|l|l||}
\hline \multicolumn{1}{|c|}{ NAME } & JOB TITLE & COMMUNITY TITLE (S) \\
\hline 22. & & \\
\hline 23. & & \\
\hline 25. & & \\
\hline 26. & & \\
\hline 27. & & \\
\hline 28. & & \\
\hline 29. & & \\
\hline 30. & & \\
\hline 31. & & \\
\hline 32. & & \\
\hline 33. & & \\
\hline
\end{tabular}




\section{Letter to Selected VIPs on Class Progress}

(Date)

(Inside Address)

Dear :

Several weeks have passed since you attended the Opening Ceremony honoring our charter class members of Sunshine County Community Leadership program. You will be pleased to know that the classes are going extremely well.

We invite you to drop by or attend any of the remaining classes as your schedule permits. The enclosed schedule card lists dates and class locations. We welcome your participation.

Sincerely,

(Singed by appropriate cosponsor representative)

Enclosure 
Attachment 5

Attendance Roster

\begin{tabular}{|c|c|c|c|c|c|c|c|c|c|c|c|c|c|}
\hline \multirow[t]{2}{*}{ Name } & \multicolumn{13}{|c|}{ Date andClass } \\
\hline & 1 & 2 & 3 & 4 & 5 & 6 & 7 & 8 & 9 & 10 & 11 & 12 & GR \\
\hline \multicolumn{14}{|l|}{1.} \\
\hline \multicolumn{14}{|l|}{2.} \\
\hline \multicolumn{14}{|l|}{3.} \\
\hline \multicolumn{14}{|l|}{4.} \\
\hline \multicolumn{14}{|l|}{5.} \\
\hline \multicolumn{14}{|l|}{6.} \\
\hline \multicolumn{14}{|l|}{7.} \\
\hline \multicolumn{14}{|l|}{8.} \\
\hline \multicolumn{14}{|l|}{9.} \\
\hline \multicolumn{14}{|l|}{10.} \\
\hline \multicolumn{14}{|l|}{11.} \\
\hline \multicolumn{14}{|l|}{12.} \\
\hline \multicolumn{14}{|l|}{13.} \\
\hline \multicolumn{14}{|l|}{14.} \\
\hline \multicolumn{14}{|l|}{15.} \\
\hline \multicolumn{14}{|l|}{16.} \\
\hline \multicolumn{14}{|l|}{17.} \\
\hline \multicolumn{14}{|l|}{18.} \\
\hline \multicolumn{14}{|l|}{19.} \\
\hline \multicolumn{14}{|l|}{20.} \\
\hline \multicolumn{14}{|l|}{21.} \\
\hline 22. & & & & & & & & & & & & & \\
\hline
\end{tabular}




\begin{tabular}{||l|l|l|l|l|l|l|l|l|l|l|l|l|l||}
\hline 23. & & & & & & & & & & & & & \\
\hline 24. & & & & & & & & & & & & & \\
\hline 25. & & & & & & & & & & & & & \\
\hline 26. & & & & & & & & & & & & & \\
\hline 27. & & & & & & & & & & & & & \\
\hline 28. & & & & & & & & & & & & & \\
\hline 29. & & & & & & & & & & & & & \\
\hline 30. & & & & & & & & & & & & & \\
\hline 31. & & & & & & & & & & & & & \\
\hline 32. & & & & & & & & & & & & & \\
\hline 33. & & & & & & & & & & & & & \\
\hline Totals & & & & & & & & & & & & & \\
\hline
\end{tabular}

Suggested Marking System:

Present - Check mark

Arrive Late or Leave Early - Check mark with minus

Absent - Cross Mark

Total Average Attendance:

Graduate Percentage: $\%$ $\%$ 


\section{Trophy Shop Order}

Address

Plaque Order Form for

Sunshine County Community Leadership

\section{COUNTY INFORMATION}

County Director/Agent:

Mailing Address:

Telephone:

\section{PLAQUE INFORMATION}

County Name:

Cosponsor Names:

Graduation Date: Quantity:

Date Needed

TOTAL ENCLOSED @ $\$ 10.00$ per plaque $\$$

(Includes shipping and handling)

List names on reverse side of this form.

*Please allow 2 weeks for printing and delivery time.

Company contacts: John Doe and Cathy Roe 


\section{NAMES}

(Please type names as they should appear on each plaque.)

\begin{tabular}{||l|l||}
\hline 1. & 21. \\
\hline 2. & 22. \\
\hline 3. & 23. \\
\hline 4. & 24. \\
\hline 5. & 25. \\
\hline 6. & 26. \\
\hline 7. & 27. \\
\hline .8. & 28. \\
\hline 9. & 29. \\
\hline 10. & 30. \\
\hline 11. & 31. \\
\hline 12. & 32. \\
\hline 13. & 33. \\
\hline 14. & 34. \\
\hline 15. & 35. \\
\hline 16. & 36. \\
\hline 17. & 37. \\
\hline 18. & 38. \\
\hline 19. & 39. \\
\hline 20. & 40. \\
\hline
\end{tabular}




\section{Letter 9}

\section{Graduation Invitation to Class Participants}

(Date)

(Inside Address)

Congratulations (Participant's Name)!

Announcing your graduation from Sunshine County Community Leadership is indeed a pleasure. It seems only a few weeks ago when you made the commitment to complete this program.

Since (beginning date), you have been actively involved in learning new leadership skills and refining existing ones. You and your class have made us all proud! Sunshine County is bound to benefit from the leadership talents of this special class.

We look forward to honoring you at a graduation dinner on:

Date:

Time:

Location:

${ }^{*}$ Dinner cost: $\$$ per person (Your spouse or guest is also invited to attend) 
Please return the bottom portion of this letter no later than (date) to make dinner reservations for you and your spouse (guest).

Here's to the Class of (Year).

(Signed by Cosponsors)

${ }^{*}$ Omit the dinner cost for the participant if cosponsors can pay it.

\section{CLIP}

I will not be able to attend.

Yes, I will attend. I have enclosed:

$\$$ Dinner cost

$\$$ Guest

$\$ \quad$ TOTAL ENCLOSED

Please make check payable to (County) Extension Service and return to:

(County Director/Agent name)

(Mailing address)

(Telephone number)

Signed: 


\section{Letter to Graduation Speaker}

(Date)

(Inside address)

Dear:

Having you deliver the commencement address to our Sunshine County Community Leadership Graduation Ceremony is indeed a pleasure, (name). Ceremony details are as follows.

Invocation (if dinner is served)

Welcome and Opening Remarks

Recognition of Sponsors and Contributors

Two or three testimonials from class members sharing different perspectives of what the program has meant to them

Keynote Address

Awarding of plaques to qualified class members

Closing comments

Thank you for taking the time from your busy schedule to speak at our graduation ceremony.

Sincerely,

(Signed by appropriate cosponsor representative) 
Letter 11a

\section{Graduation Invitation to VIPS Who Attended Opening Ceremony}

(Date)

(Inside Address)

Dear :

Announcing the graduation ceremony for Sunshine County Community Leadership is indeed a pleasure. It seems only a few weeks ago that you attended the reception in honor of this program and its participants.

Since (beginning date), the participants have been actively involved in learning new leadership skills and refining existing ones. You will be proud of what they have accomplished during this time. Sunshine County is bound to benefit from the leadership talents of this special class.

Please come and be a part of honoring this special group:

Date:

Time:

Location:

Dinner cost: \$ per person (Your spouse or guest is also invited to attend.) 
Thanks for returning the bottom portion of this letter no later than (date). This program and its participants depend on continued support from leaders such as you. We hope you can be with us on the (day).

Here's to the Class of (Year).

(Signed by Cosponsors)

I will not be able to attend.

Yes, I will attend. I have enclosed:

$\$$ Dinner cost

$\$$ __ Guest

$\$ \_$TOTAL ENCLOSED

Please make check payable to (County) Extension Service and return to: (County Director/Agent name, Mailing address, telephone and signature.) 


\section{Graduation Invitation Letter to VIPs Who did not Attend Opening Ceremony}

(Date)

(Inside Address)

Dear :

Announcing the graduation ceremony for Sunshine County Community Leadership is indeed a pleasure. It seems only a few weeks ago that you attended the reception in honor of this program and its participants.

Since (beginning date), the participants have been actively involved in learning new leadership skills and refining existing ones. You will be proud of what they have accomplished during this time. Sunshine County is bound to benefit from the leadership talents of this special class.

Please come and be a part of honoring this special group:

Date:

Time:

Location:

Dinner cost: $\$ \_$per person (Your spouse or guest is also invited to attend.)

Thanks for returning the bottom portion of this letter no later than (date). This program and its participants depend on continued support from leaders such as you. We hope you can be with us on the (day).

Here's to the Class of (Year).

(Signed by Cosponsors)

I will not be able to attend.

Yes, I will attend. I have enclosed:

$\$$ ___ Dinner cost

$\$$ Guest

$\$$ \$_TOTAL ENCLOSED

Please make check payable to (County) Extension Service and return to: (County Director/Agent name, Mailing address, telephone and signature.) 


\section{Graduation Invitation Letter to Class Instructors}

(Date)

(Inside Address)

Dear :

You are invited to attend the Sunshine County Community Leadership Graduation Ceremony. It would be a pleasure to have you with us since your participation in this program helped make it a success.

The graduation ceremony details are:

Date:

Time:

Location:

Dinner Cost: \$_ per person (Your spouse or guest is also invited to attend.)

Thanks for returning the bottom portion of this letter no later than (date).

(Signature of County Faculty)

I will not be able to attend.

Yes, I will attend. I have enclosed:

$\$$ Dinner cost

$\$$ Guest

$\$ \_$TOTAL ENCLOSED

Please make check payable to (County) Extension Service and return to: (County Director/Agent name, Mailing address and telephone number) 


\section{Graduation Invitation Letter to Advisory Committee Members}

(Date)

(Inside Address)

Dear :

Announcing the graduation for Sunshine County Community Leadership is indeed a pleasure. It seems only a few weeks ago we were planning this program. Your contribution to the Advisory Committee has been invaluable. Since (beginning date), the participants have been actively involved in learning new leadership skills and refining existing ones. You will be proud of what they have accomplished during this time. Sunshine County is bound to benefit from the leadership talents of this special class.

Please come and be a part of honoring this special group:

Date:

Time:

Location:

Dinner cost: \$_ per person (Your spouse or guest is also invited to attend.) Thanks for returning the bottom portion of this letter no later than (date). This program and its participants depend on continued support from leaders such as you. We hope you can be with us on the (day).

Here's to the Class of (Year).

(Signed by Cosponsors)

I will not be able to attend.

Yes, I will attend. I have enclosed:

$\$$ __ Dinner cost

$\$$ Guest

$\$ \_$TOTAL ENCLOSED

Please make check payable to (County) Extension Service and return to: (County Director/Agent name, Mailing address, telephone and signature.) 


\section{Sample Program for Opening Ceremony}
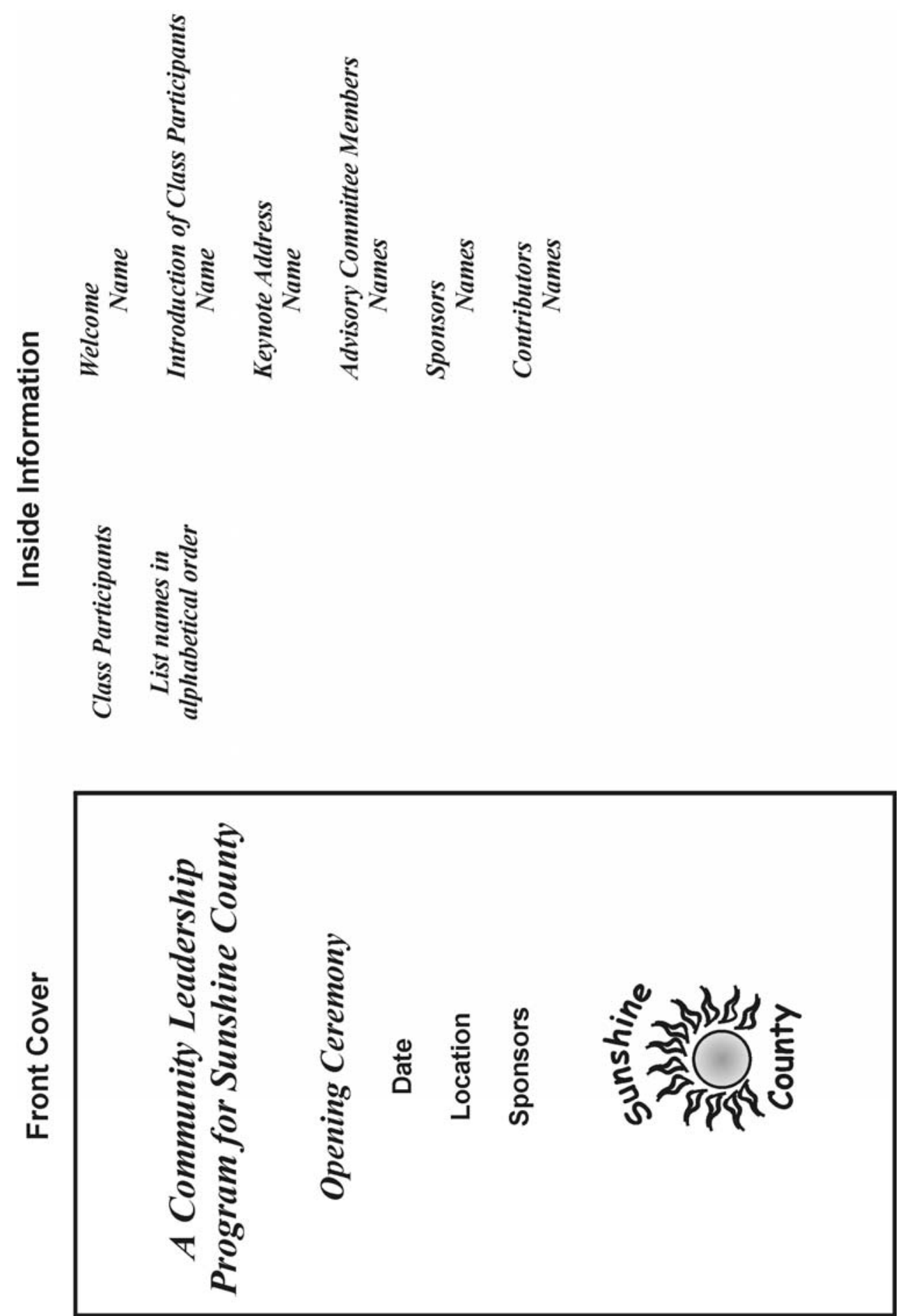
Attachment 8

\section{Sample Program for Graduation}
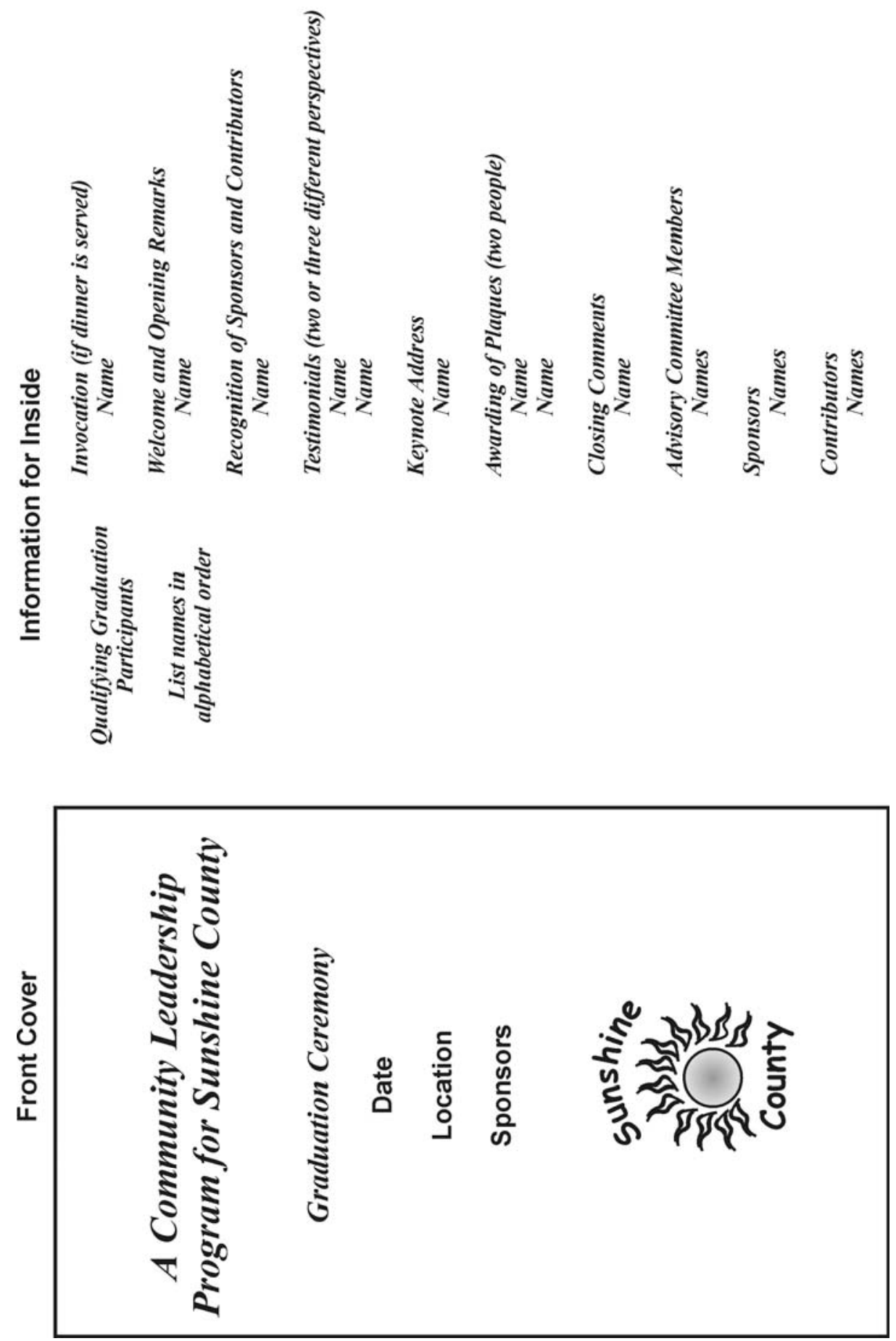
Attachment 9

Sample Physical Arrangement for Opening Ceremony and/or Graduation
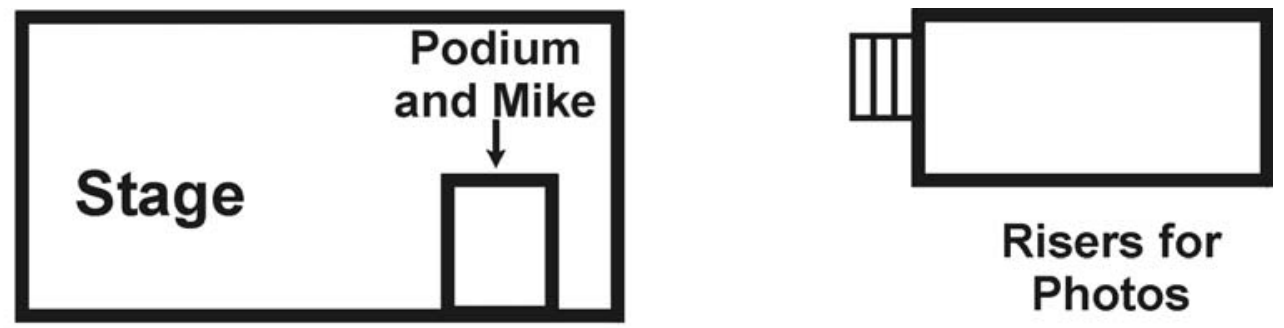

Risers for

Photos
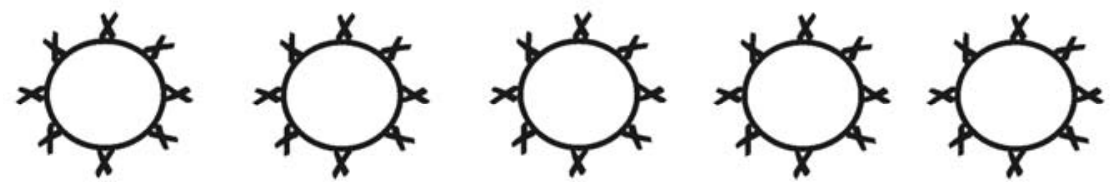

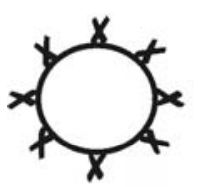

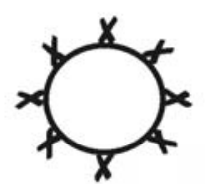

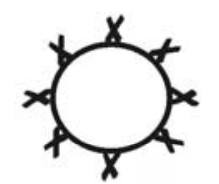

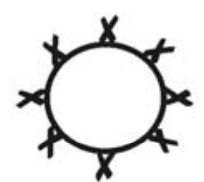

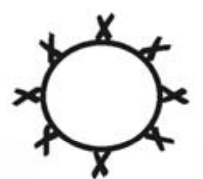

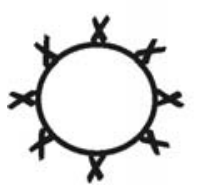

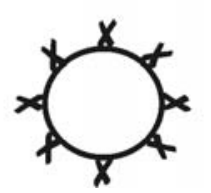

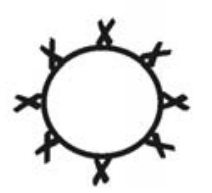<smiles>C=C1C(=C)C(=C)C(=C)C(=C)C(=C)C(=C)C(=C)C(=C)C(=C)C1=C</smiles>

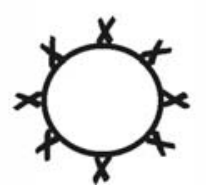




\section{Section 7}

\section{Publicity and Media Package}

\section{Timing:}

Two to three months in advance, prepare and print any announcements and flyers, or other promotional materials. Develop a mailing list for these mailings or for any newsletter.

One month to two weeks prior to the Opening Ceremony and Graduation Ceremony, contact the media. Give them the schedule of what you have planned, any contacts who can be quoted, and any news releases or background material you have prepared.

From this point up to the event, cooperate with the media in any way you can. Have material ready, take time to talk to them and answer any questions, give them information on the times, the locations, the program and anything else in writing.

A sample news release is attached for your use with this program. If you choose to prepare news releases yourself, a schedule could include:

- A series of articles about leadership to run each week until the event;

- A general announcement story about the training program;

- An announcement about the participants or the speakers;

- An interview with a local leader about the need for leadership training;

- A summary of the training including interviews with participants and their ideas on how it can improve their own skills and benefit the community.

During the training, you may not want media representatives present if you have open discussion. However, if you have a speaker who would make a good story, you can invite the public and/or the media. Be careful not to refuse the media. If you don't want them there, just don't invite them.

If media people come to an event, be sure they get the information they need. If they want to take photographs, arrange the shots they need. If they prepare an interview with a speaker, see that the speaker has the time and a quiet location to accommodate them.

If your local media want you to supply them a news article or photograph after an event, 
be sure you handle it immediately. Give them what they want typed, double-spaced in news style with black and white photographs.

Following the training, consider encouraging your local media to interview some of the students about leadership and what they learned. It makes an excellent local humaninterest story, airs important issues and concepts, and shows off the training offered by your program.

If media people give you good coverage, take the time to thank them, either formally or informally.

\section{Basic tips for dealing with the media:}

1. Remember to include who, what, when, where, why, and how (5 w's and an h.)

2. Keep your sentences short.

3. For interviews, be prepared with written notes. Check quotes to see if they are accurate.

4 Put your name, address, and phone number in the top left corner so the editor can reach you if he/she has questions. 


\section{Section 8}

\section{Meeting Preparation}

A. Facilities

1. Location - Considerations

2. Availability of meeting rooms in your community

B. Class Seating Arrangements (Attachment 10)

C. Chairs

1. Fitting the occasion

2. Criterion of success

D. Tables

Dimensions, room size, number of people and seating arrangements

E. Other Consideration

1. Provisions for the handicapped

2. Adequate parking for vehicles

F. Audiovisual Aids and Equipment

1. What do resource persons need?

2. Set up and check it out.

3. Lectern and chalkboard

4. Cords

5. Anticipate needs

G. Speakers

Information needed:
a. Who
b. Where
c. What
d. Why

H. Ideas and Plans: Class meetings

1. Name tents and/or tags

2. Candy mints

3. Snacks/drinks 
4. Introductions/name sheets

5. Slack time before meeting start

6. Start on time

7. Cosponsors

8. Class evaluations

I. Opening Ceremony and Graduation

1. Purpose

2. Inform

3. First impression

4. Form

J. Before Each Event

1. Date

2. Time

3. Facilities

4. VIPs and guests

5. Contributors

6. Press

7. Photographers

8. Speakers

9. Local merchants

10. Program plan

11. Platform decorations

12. Sound system

13. Name badges

14. Child care

15. Planned meal

16. Reception

K. Day of the Event

1. Head table

2. Seating areas

3. Head table flowers

4. Sound system

5. Water and glasses for speakers

6. Directional signs if needed

7. Welcoming committee

8. Name tags

9. Time on the program for speakers 
10 Announce place and time for class 1

11. Display plaques for graduation ceremony

L. Special Touches

1. Music

2. Souvenir photograph

3. Plan creatively

M. After the Event

1. Review and note:

a. Comments by VIP's and guests

b. Successful ideas worth repeating

c. Problems and recommended corrections

2. Prepare thank you letters for mailing to all who assisted

3. Verbal thanks to staff

4. Ask staff opinion on improvements for next session

5. Reflections and notes to yourself 


\section{Sample Classroom Arrangement}

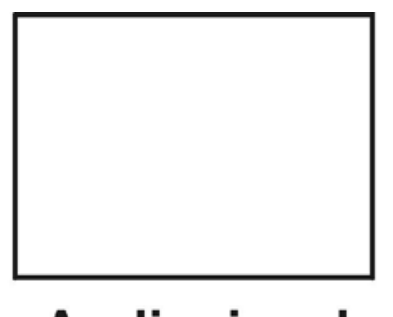

Audiovisual Screen

Chalkboard

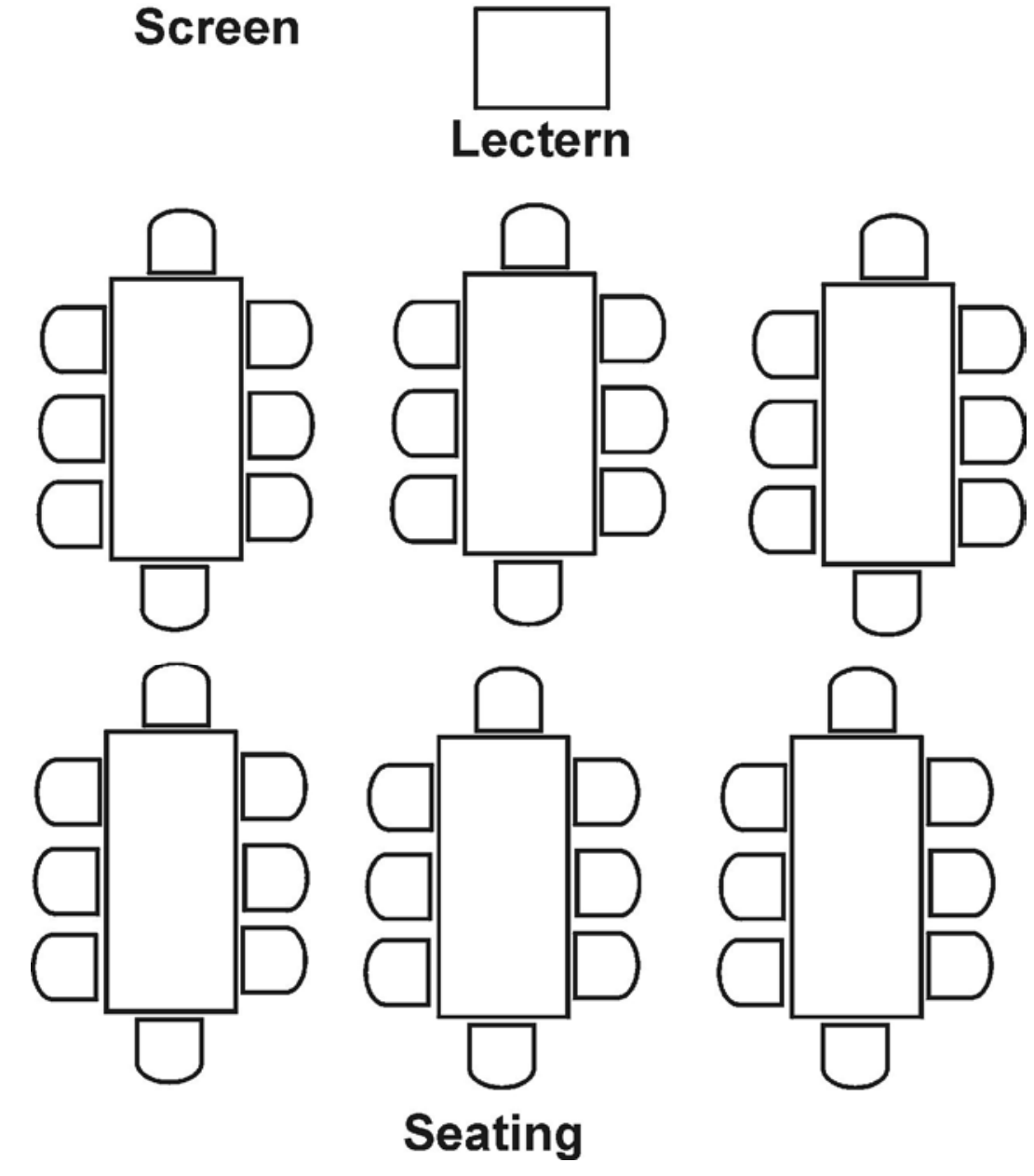




\section{Section 9}

\section{Resource Directory}

A. When you contact people, keep in mind to:

1. Identify yourself and your involvement in the Community Leadership Program

2. Explain exactly what you would like the person/group to do, e.g. speak at graduation, serve as a panel member, provide an indepth report, arrange a tour/visit.

3. Give the date, time, location, etc. If you have any flexibility to work around the individual's schedule, let them know.

4. Ask if any fee or reimbursement for travel will be required.

5. Send a follow-up letter confirming arrangements you have made and include a class roster and/or other information that will help the person relate to your group.

B. Identifying Resources

1. Match to your program goals.

2. Evaluate resources to make sure they can be used.

3. Recruit the resources that lie both within and outside every community in your county.

4. Local level resources

5. Voluntary associations and clubs

6. Community councils or groups

7. Educational institutions

8. Religious organizations

9. Business and Industry

10. Local government agencies/boards

11. Social Service Agencies

12. Mass media

13. Influential Citizens

C. Area level resources

1. Libraries

2. Community colleges

3. Cultural centers and arts associations 
D. State Level

1. University of Florida

2. Government agencies

3. Corporate Economic Developers

4. Florida Cooperative Extension Service

5. Chief Executive Officers from business/industry

6. Florida State Rural Development Council

E. Potential Speakers for Opening Ceremony and Graduation

1. Legislators

2. School Officials

3. CEO's

4. County and City Commissioners

5. Extension faculty, state and county

6. County and city government officials

F. Class Descriptions

One or two sentences on each class

G. Instructor Information

One or two sentences on each instructor

H. Things to remember

To teach leadership skills, give people opportunities to lead. 


\section{Section 10}

\section{Data Collection and Evaluation}

Data Collections Items

1. Attendance Roster

2. Record of Local Contributions

3. After Session Participation Evaluations of Classes

4. Six month follow-up evaluations from each participant
a. Focus group
b. Phone Survey
c. Mail Survey 


\section{Record of Local Contributions Sunshine County}

$\underline{\text { Cash }}$

Registration fees:

Participants @ \$ each

$\$$

Cash Donations

$\$$

Total Cash Contributions

$\$$

\section{In-Kind}

The following items are among those considered as in-kind contributions because they were donated in behalf of the program: flowers, food/refreshments, facility space, printing, photography, postage, special newspaper/media coverage, outside secretarial assistance, transportation/ vehicles for trips, etc. Please list in-kind contributions below and assign a dollar value to each:

1.

2.

3.

4.

5.

6.

7.

8.

9.

10.

Total In-Kind Contributions

$\$$

Grand Total (Cash \& In-Kind)

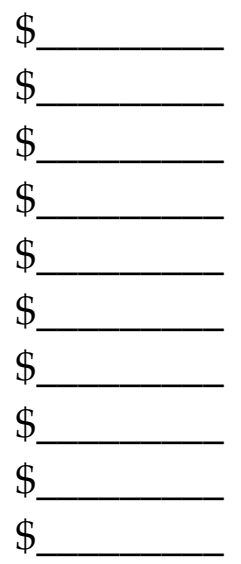

$\$$

$\$$ 
Attachment 11

\section{Sample Evaluation \\ Leadership Development Program for Sunshine County}

We are interested in your opinions about all the aspects of the Leadership Development Program for Sunshine County. We will use the information provided by this evaluation when we plan other leadership programs.

Please circle the appropriate response and add any comments that you feel will be helpful to us.

\section{Understanding Your Leadership Potential}

How much knowledge did you obtain from this session?
A lot
Some
A little
None

How likely are you to use this knowledge to become more involved in community leadership?

Not at all likely

\section{Comments:}


2. Communication Skills Needed for Leadership

How much knowledge did you obtain from this session?
A lot
Some
A little
None

How likely are you to use this knowledge to become more involved in community leadership?

Very likely

Most likely

Somewhat likely

Not at all likely

Comments:

3. The Process of Working Successfully with Other Groups

How much knowledge did you obtain from this session?
A lot
Some
A little
None

How likely are you to use this knowledge to become more involved in community leadership?
Very likely
Most likely
Somewhat likely
Not at all likely

\section{Comments:}


4. Identifying and Understanding Local Issues

How much knowledge did you obtain from this session?
A lot
Some
A little
None

How likely are you to use this knowledge to become more involved in community leadership?

Very likely Most likely Somewhat likely Not at likely

\section{Comments:}

5. Identifying and Attaining Group Goals

How much knowledge did you obtain from this session?

A lot

Some

A little

None

How likely are you to use this knowledge to become more involved in community leadership?

Very likely

Most likely

Somewhat likely

Not at all likely

Comments: 


\title{
Section 11
}

\begin{abstract}
Alumni Activities
\end{abstract}
A. Elect one or more class spokesperson(s) or liaison(s) to maintain contact with the group and program sponsors.

B. Select activities that the class did not participate in because of the limited time factor.

C. Continue special-interest committees and/or study groups that were initiated through the class:

1. Meet periodically.

2. Continue media coverage

3. Mail updates to class members

4. Seek support resources locally

D. Involve the leadership alumni group in other local Extension activities.

E. Print a directory of class members.

F. Promote the next leadership class.

G. Sponsor community forums on local issues - public issues education.

H. Serve as informal advisory group to county and city governments. 


\section{Sunshine County Community Leadership}

\section{Participant Recommendations}

As a participant in the current Sunshine County Community Leadership program, you are in a position to suggest others who might benefit from being in this class. It is extremely vital to the overall success of the program that participants within each class represent the broad base of the county population considering age, race, sex, geographic location, and career backgrounds. We appreciate your diligent effort in supplying the information below on those whom you feel have a sincere interest in their community and who want to become actively involved in making our county a better place in which to live.

1. Name:

Mailing address:

Street or Box Number

City

Zip Code

Telephone:

Home

Work

I recommend this person because: 
2. Name:

Mailing address:

Street or Box Number

City

Zip Code

Telephone:

Home

Work

I recommend this person because:

3. Name:

Mailing address:

Street or Box Number

City

Zip Code

Telephone:

Home

Work

I recommend this person because: 
4. Name:

Mailing address:

Street or Box Number

City Zip Code

Telephone:

Home

Work

I recommend this person because:

Signature

Thank you for helping maintain the quality of participation in this program through recommending some of the county's finest citizens. 


\section{References}

References from many sources are reflected in the development of a County Leadership Program. Those that are used in the development of the work sheets for this service are from the following sources:

Langone, C. and Shumway, P. (1990). Community leadership: A County Perspective. Athens, GA: Cooperative Extension Service, The University of Georgia College of Agriculture.

Hougen, R., Walker, K., Templin, E. and Ayres, J. (1993). Youth and adults working together for better communities. Ames, IA: North Central Regional Center for Rural Leadership.

Clark, R. et al. (1993). Building Coalitions. Columbus, OH: Ohio Cooperative Extension Service. Ohio Center for Action on Coalition Development for Families and High Risk Youth.

More than basic leadership materials are needed for an effective program. Some other materials that provide useful tools are shown below.

Proctor \& Gamble Educational Services. (1989). Public relations guide. Cincinnati, OH.

Mellon Bank Corporation. (1985). Discover Total Resources: A Guide For Nonprofits. Pittsburgh, PA.

Bolton, E.B. (N.d.). A Guide To Citizen Participation: Communication With Public Officials. Gainesville, FL: Cooperative Extension Service. University of Florida. 


\section{Planning, Conducting, and Evaluating the Community Leadership Program}

A teaching guide produced by the Florida Cooperative Extension Service, University of Florida, Institute of Food and Agricultural Sciences. Advisory committees working with Extension County Faculty as well as other community service organizations using this guide will develop a group of local leaders with effective resolution and goal attainment skills.

The following publications are recommended for support of this teaching guide.

Download them from the IFAS web site at http://edis.ifas.ufl.edu

FSC 9061 Everyone is a Leader

FSC 9062 The Most Important Jobs: The Group Leader and the Group Member

FCS 9063 Have a Good Group

FCS 9064 Problem Solving in Groups

FCS 9065 Managing Conflict Creatively

FCS 9066 Leaders Can Communicate

FCS 9067 Listening to Hear

FCS 9068 Giving and Receiving Feedback

FCS 9069 Choices for Political Action at the Local Level

FCS 9070 Defining Public Issues

FCS 9071 Getting Involved in Public Affairs

\section{Contact Information:}

Elizabeth B. Bolton

Professor of Community Development

University of Florida

Institute of Food and Agricultural Sciences

PO Box 113010

Gainesville, FL 32611-0310

(352) 392-1987 ext. 254

ebbolton@ifas.ufl.edu 